FACTA UNIVERSITATIS

Series: Linguistics and Literature Vol. 16, N² 2, 2018, pp. 85-105

https://doi.org/10.22190/FULL1802085J

Original Scientific Paper

\title{
ENGLISH AND SERBIAN NOMINAL FINITE AND NON-FINITE CLAUSES IN CONTRAST
}

\author{
UDC 811.111'367.3:811.163.41'367.3 \\ 811.111'243-057.87(497.11)
}

\section{Ljiljana Janković}

University of Niš, Faculty of Philosophy, English Department, Niš, Serbia

\begin{abstract}
This paper explores the extent to which Serbian tertiary-level EFL students avoid using English non-finite nominal clauses. It is comprised of a theoretical part, which describes and classifies English and Serbian nominal finite and non-finite clauses with the purpose of contrasting them as regards their syntactic functions of subject and complements, and an empirical part, which presents the results of the empirical research conducted. The method used is contrastive analysis together with description and classification. The contrasting model obtained in this way leads to the conclusion that English and Serbian nominal clauses differ in the number of the specific syntactic functions they perform as well as in the variety of forms. These results were tested in the empirical research conducted with tertiary-level Serbian students of English who translated the Serbian nominal finite clauses from the questionnaire into English, divided in two groups: the experimental and the test group. The analysis of the empirical research is based on the principle of whether students used finite or nonfinite nominal clauses in their translation. The results of the theoretical analysis have been confirmed by the empirical results since the students generally avoided using English nominal non-finite clauses when translating the sentences from the questionnaire.
\end{abstract}

Key words: Serbian tertiary-level EFL students, contrastive analysis, finite clauses, non-finite clauses

\footnotetext{
Submitted November 23, 2017, accepted for publication October 4, 2018

Corresponding author: Ljiljana Janković

University of Niš Faculty of Philosophy, English Department

E-mail : ljiljana.jankovic963@gmail.com 


\section{INTRODUCTION}

The grammar of a language can be defined differently. "Grammar deals with the structure of languages" (Jespersen 1933: 1), and as such, it describes the rules governing the formation of words, phrases, clauses and sentences, as well as the rules determining the meaning of these language structures (Huddleston and Pullum 2002: 3). "The grammar of each language constitutes a system of its own, each element of which stands in a certain relation to, and is more or less dependent on, all the others" (Jespersen 1933: 1). However, that system is neither rigid nor closed but rather prone to changes and largely depending on numerous factors, both interlingual (environment, surroundings, the level of education of the speakers of that language, economy of the community that uses that language, various registers and situations in which a particular style is used, etc.) and intralingual ones (changes within the language itself, its being open to foreign influences, flexibility of grammar structures, obsolete structures, etc.). These factors are interrelated and they have an instantaneous impact on a language and its grammar. The imperfectability of language is accorded with the imperfectability of human nature since it is through language understood as a system of habits that people endeavour to express their thoughts, emotions, intentions, wishes and actions to other members of their community. However, not all the members of one community that share the same language use it in the same way on various occasions and under different circumstances. "Grammatical expressions have been formed in the course of centuries by innumerable generations of illiterate speakers, and even in the most elevated literary style we are obliged to conform to what has become, in this way, the general practice. Hence many established idioms which on closer inspection may appear to the trained thinker illogical or irrational. The influence of emotions, as distinct from orderly rational thinking, is conspicuous in many parts of grammar - see, for instance, the chapters on gender, on expanded tenses, and on will and shall" (Jespersen 1933: 15). Besides, the linguistic discourse is not a mere transfer of unconnected words, but it rather involves phrases, clauses, sentences, sentence fragments, etc. Despite the fact that each language respects certain standards governing its use, these standards are frequently overlooked or avoided in everyday speech and oral communication so that speakers often produce only sentence fragments or phrases diverging from the prescribed language standard. However, written language has to conform to all the grammar rules of that language and produce grammatically accepted and structurally correct phrases, sentences and texts. Speaking has a lot of advantages in comparison to writing, one of them being that speakers of a language may use all the extralinguistic elements that contribute to the uniqueness and beauty of speech - body language, accent, facial expressions, the pitch of the voice, etc. This proves that human emotions influence and determine oral communication more than rational grammar rules. On the other hand, written language makes use of punctuation, underlining, italics, different fonts, various formatting of cases, etc. in order to accomplish the same goal - an appropriate comprehension of what is written.

Students of a foreign language should be taught the rules that determine the use of that language. However, besides prescriptive grammar, foreign language students should be taught descriptive grammar since it describes the way in which the native speakers of that language speak and write with the purpose of a better scholarly understanding of the grammar rules these speakers apply instinctively when using their own language. Moreover, the grammar taught has to be explanatory and explain the reasons why certain language structures are used in a particular way and with a particular frequency. These 
reasons may be of a phonemic or psychological nature, or simply caused by the historical changes that occurred so that, for instance, some structures that used to be only divergences later became the rule. Thus, a better understanding of a studied foreign language requires the knowledge of its historical development. Finally, grammar of a language is divided into morphology, the study of the word formation, and syntax, the study of sentence structures and use of language constructions. The research presented in this paper does not discuss these two fields separately but as interrelated and interconnected. The study and the analysis of forms and functions of finite and non-finite nominal clauses in English and Serbian are based on both morphological and syntactical description of these structures, with a greater emphasis placed on their use and functions in sentences.

\subsection{The subject of the paper}

This paper describes and analyses the instances in which tertiary-level Serbian EFL students avoid using English nominal non-finite clauses in the syntactic functions of complements. The paper defines them as a students' learning strategy of avoiding these structures in the English language. The starting premise is that they avoid using nominal non-finite clauses in contexts when they are supposed to, for a number of reasons, with interference of their mother tongue, the Serbian language, being probably the most evident one. Therefore, these "errors" are not to be treated as genuine grammatical mistakes but rather as either transitional or permanent stages in the process of foreign language study. In relation to the previously mentioned, the mistakes that Serbian tertiary-level students of English make are to be perceived as resulting from differences between two language structures, English and Serbian.

\subsection{The goal of the research}

The goal of this paper and the empirical research conducted with the Serbian EFL students is to describe the English and Serbian nominal finite and non-finite clauses with a focus on the form and syntactic function of the English nominal non-finite clauses and the way they are used by Serbian EFL students. These clauses are primarily described and classified syntactically with the purpose of presenting the similarities and differences between the two languages. The purpose of the empirical research is to determine the extent to which the Serbian EFL students use nominal non-finite clauses in the function of complements, i.e. to which extent they avoid using them and use finite structures instead, which are more common in their mother tongue ${ }^{1}$. The paper postulates two hypotheses:

1) Serbian students of English generally avoid using English nominal non-finite clauses in the syntactic functions of complements even at the tertiary level of studies, since they tend to use those grammatical forms which are similar to the grammatical forms in their native language. The reason is the differences between the two languages concerning the use of non-finite clauses.

2) Overt instruction on the functions of the English nominal non-finite clauses and their versatile forms influences positively the students' performance.

\footnotetext{
${ }^{1}$ An extensive study and corpus findings on the register distribution of verb patterns and the frequency of use of non-finite clauses as complements is to be found in Biber et al. (1999: 693-759). Moreover, the importance of nonfinite clauses in certain registers in English, especially the formal and literary, as well as in everyday use and conversation, is particularly discussed and explored in Egan (2008: 1-17).
} 


\subsection{The corpus}

The corpus is comprised of students' translations of the purposefully constructed Serbian sentences from a questionnaire containing finite nominal clauses that function as complements which are expected to create problems to Serbian students because of the interference of their native language. The syntactic functions they perform in the Serbian sentences are the same as the ones performed by the nominal non-finite clauses in English. The students were divided into two groups: the experimental group (presented by the letter $\mathrm{E}$ in the empirical part of the paper), in which the students were given a lecture on forms and functions of the nominal non-finite clauses in English and Serbian after which they were required to translate the Serbian sentences from the questionnaire into English; and the test group (presented by the letter T), in which the students were asked to translate the sentences from the questionnaire without any prior instructions.

\section{THEORETICAL FRAMEWORK}

The theoretical framework is based upon contrastive analysis and error analysis within the scope of contrastive linguistics, as well as on the grammar and syntax textbooks and reference materials from both English and Serbian. Although the questionnaire is composed of Serbian sentences containing finite nominal clauses, the theoretical background starts with the classification and description of the English nominal clauses, both finite and non-finite, and proceeds to Serbian nominal clauses since the goal of the paper is to analyse how frequently Serbian EFL tertiary-level students use these grammatical structures, i.e. English non-finite nominal clauses, in their translation.

\subsection{Contrastive analysis}

Contrastive analysis (CA) is traditionally defined as belonging to the field of contrastive linguistics. It is a linguistic procedure which systematically compares and contrasts two or more languages with the purpose of discovering explicit similarities and differences between these languages (Đorđević 1987: 9), or a method which helps the analyst to ascertain in which aspects the two languages are alike and in which they differ (Filipović 1975: 13). The problem of terminological diversity has been very present throughout the twentieth century and even during the twenty-first century. Thus, various terms are used in the relevant linguistic literature according to Kurteš (2005: 111): "parallel description" (Fries 1945: 9), "differential studies" (Lee 1974: 141), "differential description" (Mackey 1965: 80), "dialinguistic analysis" (Nemser 1971: 15), "analytical confrontation" (Nemser 1971: 15) "analytical comparison" (Mathesius 1964: 60), "interlingual comparison" (Filipović 1975: 6), "comparative descriptive linguistics" (Halliday-McIntosh-Strevents 1964: 112,113), and "descriptive comparison" (Catford 1968: 159).

Serbian tertiary-level students of English as a foreign language (EFL) commonly focus their attention on the differences between their mother tongue and the target language (TL) they study. Therefore, they sometimes overlook the actual similarities that might exist between the two languages and their grammatical structures. However, grammarians have always tried to discover the elements that are similar in the native language (L1) and TL in order to facilitate the process of foreign language learning by an explicit emphasis on the shared and common structures. This idea appears to be the 
starting point of the first contrastive studies (Krzeszowski 1985: 485). The historical development of contrastive analysis is rather long and well-known. It is important to say that the modern period of its development is characterised by numerous contrastive projects, application of modern approaches to the problem of contrasting languages, close cooperation among linguists and scholars in the field and publication of a great number of papers. Contemporary contrastive studies accept novel interdisciplinary approaches in contrastive analysis so that linguists do not opt for any radical view nor do they try to find either a universal, common basis for all languages or some great differences (Kurteš 2009: 235) between the languages in contrast.

The view that contrasting languages has a theoretical and practical aspect (Johansson and Hofland 1994: 25) shows how it is a very important linguistic discipline: it contributes to the further improvement of linguistic theory, but its results can be applied in foreign language teaching. The latter studies represent contrastive analysis (Jie 2008), which constitutes a part of applied linguistics. "It suggested that the greater the difference between L1 and L2, the more difficult it would be the L1 to learn L2: the more the L1 would 'interfere' with the learning of the L2. Most errors that L2 learners made were the result of differences between L1 and L2 structure" (Wang 2008: 183). Therefore, Serbian EFL students use the habits they have acquired learning their mother tongue when studying the TL. The linguistic features of Serbian that are similar to those of English will facilitate learning (positive transfer), whereas those aspects of the L1 which are different from the grammatical and phonological system of the TL will hinder foreign language acquisition (FLA) and cause various errors (negative transfer or mother tongue interference). The differences between the two languages create learning difficulties which produce errors while the similarities between them facilitate learning (Wang 2008: 183). Lado (1957: 2) emphasises that a foreign language student compares phonological, morphological, syntactical and even cultural systems of two languages in order to understand their similarities and differences, the final goal being to predict which segments of the foreign language are easy to learn and which ones may represent a difficulty. Selinker (2008: 96) states that the pedagogical materials resulting from contrastive analysis are based on the assumptions that CA defines language as a habit and TL learning as the establishment of a new set of habits, that the major source of error is the native language owing to differences between the L1 and the L2 so that "what is dissimilar between two languages is what must be learned" (Selinker 2008: 96-97).

Thus, two versions of contrastive analysis emerge: the weak and the strong one. The proponents of the "strong" contrastive analysis insist on predicting the difficulties that might appear during the TL learning and the relevant teaching methods based on the comparison of phonological, grammatical and syntactic properties of both the native and target language. Those who support the "weak" contrastive analysis endeavour to explore those errors that students continuously make while studying a foreign language in order to define the similarities and differences between their mother tongue and the foreign language they are studying.

\subsection{Error analysis}

Error analysis was acknowledged as an important field of applied linguistics during the 1970s. Namely, since the "strong" version of contrastive analysis did not prove very useful in the pedagogical aspect, then "the study of linguistic ignorance, the investigation 
of what people do not know and how they attempt to cope with their ignorance" (James 2013: 62) became central in contrastive studies. In his seminal paper, Corder (1967) described the shift of the pedagogical interests from contrastive analysis to error analysis, which initiated numerous empirical studies that followed.

Error analysis scholars make a distinction between a mistake and an error, defining them as "technically two very different phenomena" (Brown 1994: 226):

"A mistake refers to a performance error that is either a random guess or a 'slip', in that it is a failure to utilise a known system correctly. ... Mistakes, when attention is called to them, can be self-corrected. Mistakes must be carefully distinguished from errors of a second language learner, idiosyncrasies in the language of the learner that are direct manifestations of a system within which a learner is operating at the time. An error, a noticeable deviation from the adult grammar of a native speaker, reflects the competence of the learner" (Brown 1994: 226).

Central to error analysis is the study of the source of competence errors, which are different (Richards 1971): interference errors of the mother tongue (MT), intralingual errors within the TL itself and developmental errors, reflecting the learners' attempts to construct hypotheses about their target language from their limited experience.

As a systematic study and analysis of errors, EA language acquisition is seen as involving the active participation of the learners. Errors are thus a natural phenomenon they must occur before correct language rules are completely internalized (Corder 1967; DAI Wei-dong, SHU Ding-fang 1994; CAI Long-quan 2000).

However, it must be emphasised that EA does not shed much light on the developmental route learners take - it examines a learners' language at a single point in time, and the real significance of EA cannot be confirmed without using diachronic data to describe learners' developmental stages. Namely, the types and frequencies of learners' errors change in each acquisition phase and it is rather difficult to obtain any reliable results using EA without longitudinal data of a learners' language. EA focuses on where the learner errs but ignores where they perform correctly; EA fails to account for the strategy of avoidance. For Schachter (1974) the fundamental flaw in EA is that learners do not often commit the expected errors because they tend to avoid words or structures they are not sure about. Therefore, this empirical study attempts to analyse the Serbian tertiary-level students" "errors" in light of their avoidance to use certain structures in English, non-finite nominal clauses in particular.

\subsection{English and Serbian grammar books}

The theoretical framework of the paper also comprises English and Serbian grammar books and reference materials related to the syntax of both languages.

Considering the form and function of English nominal clauses, the following materials are referred to: Jespersen, O., (1933), Essentials of English Grammar; Quirk et al., (1985), A Comprehensive Grammar of the English Language; Biber et al., (1999), Longman Grammar of Spoken and Written English; Greenbaum, S., (1996), The Oxford English Grammar; Đorđević, R., (1996), Gramatika engleskog jezika; Azar, B., (1989), Understanding and Using English Grammar; Pollock, C., (1982), Communicate What You Mean; Huddleston and Pullum, (2002), The Cambridge Grammar of the English Language. 
As regards the form and function of the Serbian nominal finite and non-finite clauses, the following grammar books are considered as relevant resources: Piper et al., (2005), Sintaksa savremenoga srpskog jezika. Prosta rečenica.; Piper, P., I. Klajn, (2013), Normativna gramatika srpskog jezika; Ž. Stanojčić, (2010), Gramatika srpskog književnog jezika; Stanojčić, Ž., Lj. Popović, (1992), Gramatika srpskog jezika; Stevanović, M., (1991) Savremeni srpskohrvatski jezik (gramatički sistemi i književnojezička norma), Savremeni srpskohrvatski jezik (gramatički sistemi i književnojezička norma) II Sintaksa; Mrazović, P., (2009), Gramatika srpskog jezika za strance.

\subsubsection{Clauses in English and Serbian grammar}

The clause may be defined as "a syntactic unit which has a subject-predicate relationship and is part of a larger unit ... a linguistic unit smaller than a sentence and larger than a phrase" (Mišić Ilić 2008: 50). It may be the main (independent, superordinate or matrix) clause and the subordinate (dependent or embedded) clause. The clause structure is based upon the "form-function distinction ... To describe the constituency of clauses, we need to distinguish the following elements of clause structure: SUBJECT (S), VERB (V), OBJECT (O), COMPLEMENT (C) and ADVERBIAL (A)" (Quirk et al. 1985: 45). As regards syntactic functions, they are divided into nominal, relative, adverbial and comparative clauses. Klajn (2005: 240) states that the relationship between the main and subordinate clause may be compared to "the role that sentence structure constituents (subject, predicate and others) play in a simple sentence" (Klajn 2005: 240), which are the functions of complements and modifiers. Serbian grammars recognize a similar division of clauses into three general types: nominal, relative (adjectival) and adverbial (Stanojčić and Popović 1992: 307; Klajn 2005: 240-241; Piper and Klajn 2013: 493).

\subsubsection{English nominal clauses}

Nominal clauses are recognized by the syntactic functions they have in a sentence: subject, subject complement, direct and indirect object, object complement, object of the preposition, complement of the noun, complement of the adjective, retained object, prepositional object as well as various catenative objects. They contain both finite and non-finite verb forms. The following are types of English nominal clauses: a) finite nominal clauses, recognised as that-nominal clauses, $w h$-interrogative nominal clauses, if/whether nominal clauses and wh-nominal relative clauses; b) non-finite nominal clauses, known as infinitive nominal clauses and -ing nominal clauses.

a) Finite nominal clauses

That-nominal clauses structure: that + subject + verb. The subordinator that may be omitted whenever the nominal clause functions as a complement, but not in case it has the function of a subject. The syntactic functions of these finite clauses are illustrated in the following example sentences:

1) That she likes horror films is known to everyone. (subject)

2) They explained to us (that) he had made a huge mistake. (direct object)

3) Their wish is (that) she will win the race. (subject complement)

4) Their wish (that) she will win the race is too optimistic. (noun complement)

5) She is happy (that) they won the race. (adjective complement) 
That-nominal clauses which function as subjects are rarely used in spoken English but are rather common and frequent in formal and written English. In order to avoid a subject that is too long, the structure known as extraposition is used (in which case these nominal clauses are known as extra-posed or shifted subjects), that is the structure whose subject is $I t$ which represents only a grammatical subject whereas the true subject of the sentence is a that-nominal clause:

6) It is obvious that most of the students did well in the exam.

6a) That most of the students did well in the exam is obvious.

Wh-interrogative nominal clauses: "the wh-word is perceived as representing the unknown piece of information, the same as in regular $w h$-interrogatives. Particularly when functioning as direct objects, these clauses are perceived as indirect wh-questions" (Mišić Ilić 2008: 126). The $w h$-word functions as a true subordinator linking the nominal and main clause. Yet, unlike the subordinator that, the wh-word has its function within the nominal clause, which may be that of a subject, direct object, adverbial modifier, determinator, etc. Numerous syntactic functions of these nominal clauses as well as of the wh-word (AM - adverbial modifier, SV - subject, DO - direct object) are illustrated in the following example sentences:

7) What she accomplished still represents a miracle. (subject/AM)

8) Her question is who will start the meeting. (subject complement/SV)

9) We don't know what he expects from us. (direct object/DO)

10) They believed in what would be done. (object of the preposition/SV)

11) We never accepted the reason why she quit the job. (noun complement/AM)

12) She is not certain what will happen. (adjective complement/SV)

If/whether nominal clauses structure: if/whether + subject + verb. The subordinator if/whether links the nominal clause to the rest of the sentence and has no syntactic function of its own. The syntactic functions of this type of nominal clauses are illustrated in the following examples:

13) Whether the games will start on time depends on the weather. (subject)

14) No one knows whether the games will start on time. (direct object)

15) The problem is if the weather will change tomorrow. (subject complement)

16) Her decision to participate in the games depends on whether she will feel well or not. (object of the preposition)

17) Her decision whether to participate in the games or not depends on her present state of mind. (noun complement) complement)

18) She is not certain if she can participate in the games or not. (adjective

Wh-nominal relative clauses are analysed separately from the already described $w h$ interrogative nominal clauses. Unlike wh-interrogative nominal clauses, $w h$-nominal relative clauses begin with the subordinators which are not only $w h$-words, but also a combination of wh and ever: whoever, whatever, however, whichever, etc. The term used for them may be confusing since all English clauses are classified as nominal, relative and adverbial clauses. The reason is purely syntactic: these nominal clauses can be replaced (paraphrased) by a noun phrase containing a head word (noun) and a relative clause. Thus, the terms used for them are also free relatives and headless relatives. Their structure is the following: $W H+$ (subject) + verb. The brackets put around the subject indicate that the $w h$-word may function as both the subject and subordinator in certain examples. In fact, the wh-words are subordinators, but they have their own syntactic 
functions within the clause itself (subject, direct object, adverbial modifier, determiner, etc.). The functions of this type of nominal clauses and the subordinators they start with are illustrated in the following examples:
19) Who $(m)$ she invited to the party is none of your business. (subject) DO
20) You want to know who is coming to the party. (direct object)
SV
21) She will send the invitation to whoever wants to come. (indirect object) $S V$
22) Her party will be wherever she wants it to be. (subject complement)

$$
A M
$$
23) They will name the new hotel whatever they wish. (object complement)

$$
\text { DO }
$$
24) She can take up whichever sport she wants. (object)

b) Non-finite nominal clauses

Non-finite clauses lack some of the elements that finite clauses have (finite verb form, explicit subject, coordinators, etc.). Yet, these elements may be interpreted from the context. The example sentence (25) has a subordinator but lacks a subject. It is assumed that the subject is the same as the subject of the main clause (she), which means that this structure is considered a clause ${ }^{2}$. It is a nominal clause since it functions as a direct object, just as the corresponding finite nominal clause (25a):

25) She didn't know what to do.

25a) She didn't know what she should do.

The following are types of English non-finite nominal clauses.

Infinitive nominal clauses are classified by their structure as to-infinitive, bareinfinitive clauses, wh-clauses (29) and the infinitive nominal clauses with a subject introduced by a subordinator for (31):

26) To come all the way on foot proves his perseverance and determination. (subject)

27) She wants to stay at home tonight. (direct object)

28) All they did was play computer games all evening. (subject complement)

29) They expressed interesting ideas about where to go on holiday. (object of the preposition)

\footnotetext{
${ }^{2}$ This is explained by generative grammar whose phrase structure rules state that a clause is a structure consisting of a noun phrase and a verb phrase $(\mathrm{S}=\mathrm{NP}+\mathrm{VP})$. However, in nonfinite clauses the subject is to be detected in the deep structure: “... the syntactic component consists of a base that generates deep structures and a transformational part that maps them into surface structures. The deep structure of a sentence is submitted to the semantic component for semantic interpretation, and its surface structure enters the phonological component and undergoes phonetic interpretation. The final effect of a grammar, then, is to relate a semantic interpretation to a phonetic representation - that is, to state how a sentence is interpreted" (Chomsky 1957: 135-136). However, later, though transformations continued to be important in Chomsky's current theories, he abandoned the original notion of Deep Structure and Surface Structure and initially introduced two additional levels of representation: LF — Logical Form and PF — Phonetic Form. In the 1990s, Chomsky sketched out a new program of research known as Minimalism, in which Deep Structure and Surface Structure no longer featured and PF and LF remained as the only levels of representation. Also the meanings of Deep Structure and Surface Structure have changed over time so that the idea that the meaning of a sentence was determined by its Deep Structure was dropped for good by Chomskyan linguists when LF took over this role.
} 

complement)

30) His proposal when to throw a party was immediately accepted. (noun 31) For my friends to come on time is certainly something impossible. (subject) -ing nominal clauses

As regards this type of non-finite clauses, a distinction should be made between several -ing verb forms in the English grammar. Based on the Latin grammar, these forms are generally distinguished as participles and gerunds. However, unlike Latin or Serbian, English shows no morphological traits on the basis of which a distinction could be made regarding their form. They can be distinguished only when considered in context. The Present Participle (progressive) is thus used for constructing progressive aspect (present, past or future progressive tenses): They will be flying to London this time tomorrow. The gerund is, on the other hand, required after certain verbs, such as the verb enjoy: We enjoy going out for the weekends. Contemporary English grammars do not make formal distinctions between these verb forms and generally use the term -ing verb forms or gerund-participle verb forms. Yet, they differ considerably in their syntactic function, as well as the nominal clauses they are an integral part of. -ing verb forms which can be replaced by a nominal (noun, pronoun, noun phrase) are gerunds since they perform nominal functions, which are also the syntactic functions of the -ing non-finite nominal clauses, illustrated in the following example sentences:

32) Swimming every day is very healthy. (subject)

33) I love swimming every day. (direct object)

34) I am never tired of swimming every day. (object of the preposition)

35) My favourite pastime is swimming every day. (subject complement)

These nonfinite clauses may have an explicit subject which is in the genitive case in formal English (36), and in the objective case in informal English (37):

36) She is surprised by his (John's) coming home on time.

37) She will always remember them (her friends) water-skiing tirelessly.

\subsubsection{Serbian nominal clauses}

These subordinate clauses have the syntactic functions of a noun or noun phrase: subject, subject complement, object, object complement and adjective complement. Finite nominal clauses structure: subordinator (pronoun) da/ko/kome $. . .^{3}+$ subject + verb + omissible complements; non-finite nominal clauses structure: non-finite verb form (infinitive or present participle /glagolski prilog sadašnji/) + complements.

Syntactic functions of nominal clauses are illustrated in the following example sentences:

38) Poznato je da pušenje svakog dana škodi zdravlju. (subject)

38a) Poznato je štetno dejstvo svakodnevnog pušenja. (noun phrase as a subject)

38b) Pušiti svakog dana je štetno. (nominal infinitive clause as a subject)

38c) Poznato je da pušeći svakodnevno škodimo zdravlju ${ }^{4}$. (finite nominal clause as a subject)

39) Želeli smo da vlasti ukinu porez na imovinu. (object)

\footnotetext{
${ }^{3}$ These may be used to introduce relative clauses, as well.

${ }^{4}$ This example sentence may be rephrased as: Poznato je da mi škodimo zdravlju pušeći svakodnevno. In this case, the underlined part of the sentence is an adverbial of manner, answering the question $H O W$ ?
} 
39a) Želeli smo ukidanje poreza na imovinu od strane vlasti (noun phrase as an object).

Example (39a) shows how it is not possible to construct a non-finite nominal clause functioning as a direct object. However, in case of both main and subordinate clauses having the same subject, such a construction is quite acceptable:

39b) Želeli smo ukinuti porez na imovinu (the sentence containing the corresponding finite clause: Želeli smo da mi ukinemo porez na imovinu).

40) Naš osnovni zadatak je da vojne sile prekinu sukobe. (subject complement)

40a) Naš osnovni zadatak je prekid sukoba od strane vojnih sila. (noun phrase as a subject complement because it is impossible to construct a non-finite nominal clause in this case).

This sentence (40) may be constructed to contain a non-finite nominal clause functioning as a subject complement only in the case that both the main and subordinate clauses have the same subject:

40b) Naš osnovni zadatak je prekinuti sukobe. Prekinuti sukobe je naš osnovni zadatak (the sentence containing the corresponding finite clause: Naš osnovni zadatak je da mi prekinemo sukobe).

\subsection{Concluding remarks}

This theoretical analysis of English and Serbian nominal finite and non-finite clauses leads to certain conclusions. Contrary to the situation evident in the English language concerning nominal finite and non-finite clauses and their functions, only certain types of the Serbian nominal finite clauses can be paraphrased using only two types of non-finite nominal clauses (those containing infinitive and present participle/glagolski prilog sadašnji). Finite nominal relative clauses functioning as subjects or subject complements in a sentence can be paraphrased with infinitive nominal clauses. Also, finite nominal clauses functioning as direct objects in a sentence can be paraphrased with infinitive nominal clauses in the same syntactic function. A Serbian non-finite nominal clause with a present participle, only when having a syntactic function of a subject, is a possible paraphrase of a Serbian finite nominal clause which also functions as a subject in a sentence. Other types of Serbian finite nominal clauses can be paraphrased using noun phrases, but not using non-finite nominal clauses (Svi su čuli vest o tome da se on kandidovao za predsednika.: Svi su čuli vest o njegovoj kandidaturi za predsednika. / Shvatio je da su oni zainteresovani za tu vrstu filmova.: Shvatio je njihovu zainteresovanost za tu vrstu filmova.)

Unlike English, which is characterised by a great variety of non-finite nominal clauses concerning both their form and function, Serbian lacks this variety. This premise was a starting point for constructing a questionnaire on which the empirical research was based, since the greatest amount of mother tongue interference is expected when translating this type of clauses. The questionnaire contains purposefully constructed Serbian finite nominal clauses that may be translated into English using the English non-finite nominal clauses. 


\section{EMPIRICAL RESEARCH}

The postulated hypotheses of the paper were tested in the empirical research conducted with Serbian tertiary-level EFL students. The respondents were divided into two groups - the experimental group and the test group. The students from both groups were classified into five subgroups, judging by their translation mark in the midterm examination for the courses Contemporary English 6 (third-year students) and Contemporary English 8 (fourth-year students). Each subgroup contained five students, which means that the experimental and test group consisted of twenty-five students respectively, i.e. fifty students per academic year (third-year students and fourth-year students respectively). The research was conducted in the course of two academic years so that the total number of students that participated in the research is two hundred. The students' translations were analysed regarding the criterion whether the translated sentences contain English nonfinite nominal clauses in the syntactic function of complements. The students' translations containing finite nominal clauses or phrases, as well as grammatically incorrect or unacceptable structures, were not taken into consideration.

\subsection{The questionnaire}

Table 1 Serbian sentences from the questionnaire

\begin{tabular}{cl}
\hline $\begin{array}{l}\text { Sentence } \\
\text { number }\end{array}$ & Sentences \\
\hline 1) & Priznala je da nije uradila domaći zadatak. \\
2) & Moguće je da je završio projekat na vreme. \\
$3)$ & Nije znao gde prvo da ide. \\
$4)$ & Želeo sam da joj kažem istinu. \\
5) & Očekivao je da oni dođu na vreme. \\
$6)$ & Važno je da ljudi imaju nadu. \\
7) & Porekao je da je tamo ikada ranije bio. \\
$8)$ & Iznenada je postala svesna da je on posmatra. \\
9) & Sećam se da mi je, kada smo se prvi put sreli, pričala o svom poslednjem romanu. \\
$10)$ & Džon je pretpostavio da je stranac za šankom druželjubiv.
\end{tabular}

Based on the theoretical analysis, it is concluded that the Serbian sentences from the questionnaire containing finite nominal clauses in the syntactic functions of subject and complements can be translated into English using non-finite nominal clauses in the syntactic function of complements. The given Serbian sentences were first classified according to the syntactic function of the finite nominal clauses in them. After that, the students' translations were analysed in accordance with that classification and not respecting the order of the sentences in the questionnaire. The Serbian finite nominal clauses functioning as complements are marked with the letter $\mathrm{C}$ for clarity. 


\subsubsection{Nominal finite clauses as DO and object complement}

A number of finite nominal clauses perform these two functions:

1) Priznala je da nije uradila domaći zadatak. (Co1)

2) Želeo sam da joj kažem istinu. (Co4)

3) Očekivao je da oni dođu na vreme. (Co5)

4) Porekao je da je tamo ikada ranije bio. (Co7) $(\mathrm{Co} 9)$

5) Sećam se da mi je, kada smo se prvi put sreli, pričala o svom poslednjem romanu.

6) Džon je pretpostavio da je stranac za šankom druželjubiv. (Co10)

7) Nije znao gde prvo da ide. (Co3)

\subsubsection{Nominal finite clause as adjective complement}

One sentence from the questionnaire contains a nominal finite clause which has the function of an adjective complement:

8) Iznenada je postala svesna da je on posmatra. (Cadj8).

\subsubsection{Nominal finite clauses as subject}

Nominal finite clauses functioning as subject:

9) Moguće je da je završio projekat na vreme. (Cs2) (Da je završio projekat na vreme je moguće.)

10) Važno je da ljudi imaju nadu. (Cs6) (Da ljudi imaju nadu je važno.)

\section{DiSCUSSION OF THE RESULTS}

The results of the research are presented with respect to the goals of the study: to determine the frequency of use of non-finite nominal clauses among tertiary-level Serbian EFL students and the benefits of explicit instruction on the forms and functions of the English non-finite nominal clauses.

The students' translations are analysed according to the criterion whether the translated sentences contain finite or non-finite nominal clauses, with a special emphasis on the non-finite clauses as the structures that are inherent to the English language and whose use indicates the native speakers' proficiency. The translated sentences containing various phrases or incorrect structures are only numerically presented in the part of the paper containing the tables with overall and detailed results of the study (see 4.1 and 4.2), since they are not the focus of this research. However, prior to the discussion of the obtained results, the table containing the Serbian sentences from the questionnaire, students' translations of these sentences with non-finite nominal clauses, translations with finite clauses, translations with phrases, as well as incorrect and unacceptable translations is presented. 
Table 2 Students' translations of the Serbian sentences from the questionnaire

\begin{tabular}{|c|c|c|c|c|}
\hline Serbian sentences & $\begin{array}{l}\text { Translations - non- } \\
\text { finite }\end{array}$ & $\begin{array}{l}\text { Translations } \\
\text { finite }\end{array}$ & $\begin{array}{l}\text { Translations } \\
\text { phrases }\end{array}$ & Incorrect translations \\
\hline $\begin{array}{l}\text { Priznala je da nije } \\
\text { uradila domaći } \\
\text { zadatak. }\end{array}$ & $\begin{array}{l}\text { She admitted not } \\
\text { having done Inot } \\
\text { doing her homework }\end{array}$ & $\begin{array}{l}\text { She admitted that } \\
\text { she hadn't done } \\
\text { her homework. }\end{array}$ & & \\
\hline $\begin{array}{l}\text { Moguće je da je } \\
\text { završio projekat na }\end{array}$ & $\begin{array}{l}\text { He is likely to have } \\
\text { finished the project }\end{array}$ & $\begin{array}{l}\text { It is possible that } \\
\text { he (has) finished }\end{array}$ & $\begin{array}{l}\text { His completion of } \\
\text { the project on }\end{array}$ & $\begin{array}{l}\text { There is a possibility } \\
\text { of his finishing the }\end{array}$ \\
\hline vreme & on time. & $\begin{array}{l}\text { the project on } \\
\text { time. He might } \\
\text { have finished the } \\
\text { project on time. }\end{array}$ & $\begin{array}{l}\text { time seems quite } \\
\text { possible }\end{array}$ & $\begin{array}{l}\text { project on time. It was } \\
\text { possible for him to } \\
\text { finish the project on } \\
\text { time. It was possible } \\
\text { that he had finished } \\
\text { the project on time. }\end{array}$ \\
\hline $\begin{array}{l}\text { ije znao gde prvo } \\
\text { a ide. }\end{array}$ & $\begin{array}{l}\text { He didn't know } \\
\text { where to go first. }\end{array}$ & $\begin{array}{l}\text { He didn't know } \\
\text { where he would go } \\
\text { first. }\end{array}$ & $\begin{array}{l}\text { He didn't know } \\
\text { the right way. }\end{array}$ & $\begin{array}{l}\text { He didn't know where } \\
\text { would he go. }\end{array}$ \\
\hline $\begin{array}{l}\text { Želeo sam da joj } \\
\text { kažem istinu. }\end{array}$ & $\begin{array}{l}\text { I wanted to tell her } \\
\text { the truth. }\end{array}$ & & & $\begin{array}{l}\text { I wanted telling her } \\
\text { the truth. } \\
\text { I wanted that I } \\
\text { tell/would/could tell } \\
\text { her the truth. }\end{array}$ \\
\hline $\begin{array}{l}\text { Očekivao je da oni } \\
\text { dođu na vreme. }\end{array}$ & $\begin{array}{l}\text { He expected them to } \\
\text { come / arrive on } \\
\text { time. }\end{array}$ & $\begin{array}{l}\text { He expected that } \\
\text { they come / would } \\
\text { / could come on } \\
\text { time. }\end{array}$ & $\begin{array}{l}\text { He expected their } \\
\text { arrival on time. }\end{array}$ & $\begin{array}{l}\text { He expected for them } \\
\text { to come on time. }\end{array}$ \\
\hline $\begin{array}{l}\text { Važno je da ljudi } \\
\text { imaju nadu. }\end{array}$ & $\begin{array}{l}\text { It is important for } \\
\text { people to have hope. } \\
\text { Having hope is } \\
\text { important for people. } \\
\text { What is important } \\
\text { for people is to have } \\
\text { hope. }\end{array}$ & $\begin{array}{l}\text { It is important that } \\
\text { people have hope. } \\
\text { What is important } \\
\text { is that people have } \\
\text { hope. }\end{array}$ & & $\begin{array}{l}\text { It is important people } \\
\text { have hope }\end{array}$ \\
\hline $\begin{array}{l}\text { Porekao je da je } \\
\text { tamo ikada ranije } \\
\text { bio. }\end{array}$ & $\begin{array}{l}\text { He denied (his) ever } \\
\text { being / having ever } \\
\text { been there before. }\end{array}$ & $\begin{array}{l}\text { He denied that he } \\
\text { had ever been } \\
\text { there before. }\end{array}$ & $\begin{array}{l}\text { He denied his } \\
\text { presence there. }\end{array}$ & $\begin{array}{l}\text { He denied to have } \\
\text { ever been there } \\
\text { before / that he has } \\
\text { ever been there } \\
\text { before. }\end{array}$ \\
\hline $\begin{array}{l}\text { Iznenada je postala } \\
\text { svesna da je on } \\
\text { posmatra. }\end{array}$ & $\begin{array}{l}\text { She suddenly } \\
\text { became aware of } \\
\text { him (his) looking at } \\
\underline{\text { her. }}\end{array}$ & $\begin{array}{l}\text { She suddenly } \\
\text { became aware } \\
\text { that he was } \\
\text { looking at her. }\end{array}$ & $\begin{array}{l}\text { She suddenly } \\
\text { became aware of } \\
\text { his glances. }\end{array}$ & \\
\hline $\begin{array}{l}\text { Sećam se da mi je, } \\
\text { kada smo se prvi } \\
\text { put sreli, pričala o } \\
\text { svom poslednjem } \\
\text { romanu. }\end{array}$ & $\begin{array}{l}\text { I remember her } \\
\text { telling me about her } \\
\text { latest novel when we } \\
\text { first met. }\end{array}$ & $\begin{array}{l}\text { I remember that } \\
\text { she was telling me } \\
\text { about her latest } \\
\text { novel when we } \\
\text { first met. }\end{array}$ & $\begin{array}{l}\text { I remember her } \\
\text { talk about her } \\
\text { latest novel when } \\
\text { we first met. }\end{array}$ & $\begin{array}{l}\text { Our first encounter } \\
\text { was, I remember } \\
\text { when she told me } \\
\text { about her latest novel. } \\
\text { I remember her } \\
\text { talking me about her } \\
\text { latest novel when we } \\
\text { first met. }\end{array}$ \\
\hline $\begin{array}{l}\text { Džon je } \\
\text { pretpostavio da je } \\
\text { stranac za šankom } \\
\text { druželjubiv. }\end{array}$ & $\begin{array}{l}\text { John assumed/ } \\
\text { believed / presumed } \\
\text { the stranger at the } \\
\text { bar to be friendly. }\end{array}$ & $\begin{array}{l}\text { John supposed/ } \\
\text { believed that the } \\
\text { stranger at the bar } \\
\text { was friendly. }\end{array}$ & & $\begin{array}{l}\text { John thought that the } \\
\text { stranger at the bar is } \\
\text { friendly. }\end{array}$ \\
\hline
\end{tabular}

${ }^{5}$ The largest e-corpus available (https://corpus.byu.edu/now/, 5.7 billion words) shows no match for this example, which is the reason why it is classified as an incorrect translation. 


\subsection{Overall results}

Table 3 Overall results of the students' translations

\begin{tabular}{cccccccc} 
& & \multicolumn{2}{c}{ Non-finite clauses } & \multicolumn{2}{c}{ Finite clauses } & \multicolumn{2}{c}{ Other structures } \\
\cline { 2 - 7 } & & $\begin{array}{c}\text { number of } \\
\text { clauses }\end{array}$ & $\%$ & $\begin{array}{c}\text { number of } \\
\text { clauses }\end{array}$ & $\%$ & $\begin{array}{c}\text { number of } \\
\text { phrases and } \\
\text { incorrect } \\
\text { structures }\end{array}$ & $\%$ \\
\hline \multirow{2}{*}{ III } & $\mathbf{E}$ & 214 & 42,80 & 280 & 56,00 & 6 & 1,20 \\
& $\mathbf{T}$ & 193 & 38,60 & 296 & 59,20 & 11 & 2,20 \\
\hline \multirow{2}{*}{ IV } & $\mathbf{E}$ & 234 & 46,80 & 261 & 52,20 & 5 & 1,00 \\
& $\mathbf{T}$ & 215 & 43,00 & 276 & 55,20 & 9 & 1,80 \\
\hline
\end{tabular}

The questionnaire contained 10 Serbian sentences with finite nominal clauses functioning as subject and complements. The research was done with 200 tertiary-level EFL students in the course of two non-consecutive academic years and the corpus contained 2000 translated sentences. This table shows that both the experimental and test group produced a larger number of translated sentences containing finite nominal clauses than those with non-finite nominal clauses.

These results confirm the first hypothesis of the paper: the mother tongue interference influences the students' performance when using English non-finite nominal clauses. The results of the research are directly caused by this great difference in the number of syntactic functions of the Serbian and English non-finite nominal clauses. The overall results, though, do not confirm the second hypothesis of the paper since the experimental group demonstrated similar results as the test group.

\subsection{Detailed results}

The forthcoming part of the paper presents the results of the experimental research in detail. The results are presented considering the year of study, the academic year in which the research was conducted and the syntactic functions of the Serbian finite nominal clauses from the questionnaire and their English equivalents.

\subsubsection{Nominal clauses regarding the year of study and research}

The results of the students' translations of the Serbian nominal finite clauses from the questionnaire are presented in the following two tables regarding the year of study and the academic year in which the research was conducted.

Table 4 The third-year students' translation results

\begin{tabular}{cccccc}
\hline \multicolumn{2}{c}{ Non-finite clauses } & \multicolumn{2}{c}{ Finite clauses } & \multicolumn{2}{c}{ Other structures } \\
\hline $\begin{array}{c}\text { number of } \\
\text { clauses }\end{array}$ & $\%$ & $\begin{array}{c}\text { number of } \\
\text { clauses }\end{array}$ & $\%$ & $\begin{array}{c}\text { number of } \\
\text { phrases and } \\
\text { incorrect } \\
\text { structures }\end{array}$ & $\%$ \\
\hline 74 & 29,60 & 172 & 68,80 & 4 & 1,60 \\
92 & 36,80 & 150 & 60,00 & 8 & 3,20 \\
\hline 140 & 56,00 & 108 & 43,20 & 2 & 0,80 \\
101 & 40,40 & 146 & 58,40 & 3 & 1,20 \\
\hline
\end{tabular}


Table 5 The fourth year students' translation results

\begin{tabular}{cccccccc} 
& & \multicolumn{2}{c}{ Non-finite clauses } & \multicolumn{2}{c}{ Finite clauses } & \multicolumn{2}{c}{ Other structures } \\
\cline { 2 - 7 } & & $\begin{array}{c}\text { number of } \\
\text { clauses }\end{array}$ & $\%$ & $\begin{array}{c}\text { number of } \\
\text { clauses }\end{array}$ & $\%$ & \multicolumn{3}{c}{$\begin{array}{c}\text { number of } \\
\text { phrases and } \\
\text { incorrect } \\
\text { structures }\end{array}$} & $\%$ \\
\hline \multirow{2}{*}{$\mathbf{2 0 1 2 / 1 3}$} & $\mathbf{E}$ & 195 & 78,00 & 53 & 21,20 & 2 & 0,80 \\
& $\mathbf{T}$ & 149 & 59,60 & 98 & 39,20 & 3 & 1,20 \\
\hline \multirow{2}{*}{$\mathbf{2 0 1 4 / 1 5}$} & $\mathbf{E}$ & 39 & 15,60 & 208 & 83,20 & 3 & 1,20 \\
& $\mathbf{T}$ & 66 & 26,40 & 178 & 71,20 & 6 & 2,40 \\
\hline
\end{tabular}

Although the overall results show that tertiary-level EFL students produced more English sentences containing finite nominal clauses than non-finite ones, these two tables indicate a certain digression related to the academic year of study: the 2014/2015 thirdyear students from the experimental group translated the Serbian sentences from the questionnaire using more non-finite clauses than the finite ones. The same results are shown by the 2012/2013 fourth-year students from both the experimental and test group. This distinction, compared to the overall results, emphasizes not only the particular students' proficiency in English but also their personal interest in achieving a native speaker-like performance.

\subsubsection{Nominal clauses regarding their syntactic functions}

The Serbian sentences from the questionnaire contained nominal clauses functioning as direct objects, object complement, adjective complement and subject. The detailed results are presented in the following tables.

Table 6 Translation results of the nominal clauses as DO and object complement

\begin{tabular}{cccccccc} 
& & \multicolumn{2}{c}{ Non-finite clauses } & \multicolumn{2}{c}{ Finite clauses } & \multicolumn{2}{c}{ Other structures } \\
\cline { 2 - 8 } & & $\begin{array}{c}\text { number of } \\
\text { clauses }\end{array}$ & $\%$ & $\begin{array}{c}\text { number of } \\
\text { clauses }\end{array}$ & $\%$ & $\begin{array}{c}\text { number of } \\
\text { phrases and } \\
\text { incorrect } \\
\text { structures }\end{array}$ & $\%$ \\
\hline \multirow{2}{*}{ III } & $\mathbf{E}$ & 159 & 45,43 & 187 & 53,40 & 4 & 1,14 \\
& $\mathbf{T}$ & 147 & 42,00 & 196 & 56,00 & 7 & 2,00 \\
\hline \multirow{2}{*}{ IV } & $\mathbf{E}$ & 173 & 49,43 & 174 & 49,70 & 3 & 0,86 \\
& $\mathbf{T}$ & 161 & 46,00 & 184 & 52,60 & 5 & 1,43 \\
\hline
\end{tabular}

The presented results prove that the respondents produced a greater number of translations containing finite nominal clauses than those with non-finite ones, especially when translating sentences (5), (9) and (10) (see Table 2). On the other hand, a greater number of nominal non-finite clauses is composed when translating sentences (3), (4) and (7) (see Table 2 ). This proves the mother tongue interference in those cases in which Serbian nominal finite clauses cannot be paraphrased with non-finite ones. The students naturally applied the avoidance strategy due to a difference between L1 and TL in this particular segment. Moreover, such results are caused by the fact that in the aforementioned sentences, the main 
and subordinate clauses do not have the same subject which is further evidence that even tertiary-level EFL students avoid using those structures that they find rather too complex or feel insecure to use. This is particularly true regarding sentence (10): the subordinate clause subject is too long (the stranger at the bar) and therefore too complicated to use, so the students reached for a less complicated and safer solution - a finite nominal clause.

The questionnaire contained only one sentence (8) with a finite nominal clause in the syntactic function of an adjective complement.

Table 7 Translation results of the nominal clause as adjective complement

\begin{tabular}{|c|c|c|c|c|c|c|c|}
\hline & \multicolumn{2}{|c|}{ Non-finite clauses } & \multicolumn{2}{|c|}{ Finite clauses } & \multicolumn{2}{|c|}{ Other structures } \\
\hline & & $\begin{array}{c}\text { number of } \\
\text { clauses }\end{array}$ & $\%$ & $\begin{array}{c}\text { number of } \\
\text { clauses }\end{array}$ & $\%$ & $\begin{array}{c}\text { number of } \\
\text { phrases and } \\
\text { incorrect } \\
\text { structures }\end{array}$ & $\%$ \\
\hline \multirow{2}{*}{ III } & $\mathbf{E}$ & 21 & 42 & 28 & 56 & 1 & 2 \\
\hline & $\mathbf{T}$ & 17 & 34 & 32 & 64 & 1 & 2 \\
\hline \multirow{2}{*}{ IV } & $\mathbf{E}$ & 29 & 58 & 20 & 40 & 1 & 2 \\
\hline & $\mathbf{T}$ & 22 & 44 & 26 & 52 & 2 & 4 \\
\hline
\end{tabular}

The obtained results illustrate the already mentioned students' tendency to translate into English using mostly finite structures. However, a little digression is noticeable in the results of the experimental group of the fourth-year students who produced more sentences with non-finite nominal clauses when translating this sentence into English. This may be ascribed to both the overt instruction on nominal clauses and a generally better performance of the fourth-year students in comparison to their younger colleagues.

Two sentences from the questionnaire, (2) and (6), contained finite nominal clauses which function as subject in the Serbian language but which, when translated into English, function as adjective complements, regardless of the fact whether the translated sentences contain a finite or a non-finite clause ${ }^{6}$.

Table 8 Translation results of the nominal clauses as subject

\begin{tabular}{cccccccc} 
& & \multicolumn{2}{c}{ Non-finite clauses } & \multicolumn{2}{c}{ Finite clauses } & \multicolumn{2}{c}{ Other structures } \\
\cline { 2 - 7 } & & $\begin{array}{c}\text { number of } \\
\text { clauses }\end{array}$ & $\%$ & $\begin{array}{c}\text { number of } \\
\text { clauses }\end{array}$ & $\%$ & $\begin{array}{c}\text { number of } \\
\text { phrases and } \\
\text { incorrect } \\
\text { structures }\end{array}$ & $\%$ \\
\hline \multirow{2}{*}{ III } & $\mathbf{E}$ & 34 & 34 & 65 & 65 & 1 & 1 \\
& $\mathbf{T}$ & 29 & 29 & 68 & 68 & 3 & 3 \\
IV & $\mathbf{E}$ & 32 & 32 & 67 & 67 & 1 & 1 \\
\hline
\end{tabular}

It is clear that the respondents translated these two sentences using mostly finite structures, thus remaining consistent with their mother tongue properties. The mother

\footnotetext{
${ }^{6}$ However, this need not be the case because sentence (2) may be translated in the following way: That he finished the project on time is possible. Although marginally acceptable, this translation is acceptable nevertheless and shows that the bold part of the sentence functions as the subject.
} 
tongue interference is particularly noticeable in the translation of sentence (6), probably because the subordinate and main clauses, when translated into English using a non-finite clause, have different subjects. Serbian non-finite clauses do not have their own subject and paraphrase the finite clauses only in case of both the subordinate and main clauses having the same subject. This not being the case in the English language, in which all non-finite clauses can have their own explicit or implicit subject not necessarily identical to the subject of the main clause, presented a problem even for the tertiary-level Serbian EFL students.

The mother tongue interference is also evident in the translation of sentence (2), which illustrates a structural difference between the two languages. The English sentence structure is: $\mathrm{S}+$ be + Adj + non-finite (infinitive) clause. However, the Serbian language requires only a finite structure in this particular case. Therefore, the students translated this sentence using the structure with the grammatical subject $I t$ and that-nominal clause.

\section{CONCLUSION}

This paper is a modest attempt to describe, classify and contrast the studied finite and non-finite nominal clauses in English and Serbian and thus contribute to the further advancement of the contrastive analysis of both languages. The starting premise being the contrastive analysis, the theoretical part of this paper describes the English and Serbian nominal clauses in their syntactic function of subject and complements. The clauses are also described on the basis of the criterion whether they contain the finite or non-finite verb form in both languages. The goal of this description and contrasting is to identify the instances in which finite clauses may be paraphrased by non-finite clauses in the English and Serbian language. This contrasting procedure has been applied with the purpose of describing and direct comparing and contrasting of the English and Serbian nominal finite and non-finite clauses, which is not usually to be found presented in such a manner in grammar and syntactic reference books. Therefore, the comparison and contrastive analysis of nominal clauses in each language respectively is followed by the contrastive analysis of the English and Serbian finite nominal clauses and the contrastive analysis of the English and Serbian non-finite nominal clauses in their syntactic functions of subject and complements. Thus, three contrasting models have been created:

a) The English finite and non-finite nominal clauses in contrast

b) The Serbian finite and non-finite nominal clauses in contrast

c) The English and Serbian finite and non-finite nominal clauses in contrast

These contrasting models emphasize both the similarities and differences between this type of clauses in English and Serbian. The similarities between these structures are noticed as regards their general syntactic functions, which are that of complements and subject in both languages. The differences are identified in relation to their specific syntactic functions, frequency of use and variety of their form. English non-finite nominal clauses (infinitive and ing clauses) have a greater number of specific syntactic functions than the Serbian ones. Serbian infinitive nominal clauses function as subject, direct object, indirect object and noun complement, whereas non-finite nominal clauses with a present participle (glagolski prilog sadašnji) function as subject. Besides these functions, English non-finite nominal clauses have two more syntactic functions: adjective complement and object of the preposition. However, a more significant distinction is observed in a variety of forms: there are six infinitive forms and four -ing forms in English which are used to construct a variety of nominal non-finite clauses; 
on the other hand, there is only one form of infinitive and only one form of present participle (glagolski prilog sadašnji) in Serbian and therefore a smaller number and variety of nominal non-finite clauses.

The results obtained from the empirical research confirm the first hypothesis of the paper: that mother tongue interference greatly determines the tertiary-level students' performance in this particular segment of grammar. However, the second hypothesis about the importance of overt instruction is not confirmed, taking the overall results into account. Yet, the detailed analysis of the corpus shows that lecturing on grammar does yield some note-worthy results (see Table 4 and Table 5). Moreover, establishing whether there is any actual statistical significance in the obtained results might be a fruitful direction to follow in some future research. This paper analyses only one segment of grammar of two languages, English and Serbian, which is nominal clauses in their syntactic function of subject and complements. As regards the nature of the examined corpus, comprised of the translation of the Serbian sentences from the questionnaire, the very scope of this research is limited, i.e. the paper analyses and discusses only the translation of the Serbian finite nominal clauses into English non-finite nominal clauses in order to determine the extent to which these structures are used by Serbian students of English. In other words, it would be very useful to examine other grammatical structures that Serbian tertiary-level EFL students use when translating the aforementioned Serbian sentences (phrases, for example). Also, incorrect and grammatically unacceptable translations represent the material for some future study. In conclusion, the research conducted raises new questions related to the use and classification of the English and Serbian non-finite nominal clauses and to the issues of teaching about these clauses, which can contribute to the students' higher competence and better performance in this area of grammar and thus reduce their mother tongue interference.

\section{REFERENCES}

Chomsky, N., (1968), Language and Mind, Harcourt, New York.

Azar, B., (1989), Understanding and Using English Grammar, 3rd edition, New Jersey, Prentice Hall Regents, Eaglewood Cliffs.

Biber, D., Johanson, S., Leech, G., Conrad, S. and Finegan, E., (1999), Longman Grammar of Spoken and Written English, Longman, London.

Brown, D. B., (1994), Principles of Language Learning and Teaching, Prentice Hall, New Jersey.

Catford, J. C., (1968),"Contrastive analysis and language teaching”, J. E. Alatis (ed.), Contrastive Linguistics and its Pedagogical Implications, Georgetown University Press, Washington D. C., pp. 159-173.

Corder, S. P., (1967),"The Significance of Learner's Errors", Weinheim, Julius Beltz, International Review of Applied Linguistics, V/4, https://www.scribd.com/doc/54466787/Corder-S-P-1967-the-Significance-ofLearners-Errors-International-Review-of-Applied-Linguistics-5-161-169.

Đorđević, R., (1987), Uvod u kontrastiranje jezika, Zavod za udžbenike i nastavna sredstva, Beograd.

Đorđević, R., (1996), Gramatika engleskog jezika, Čigoja štampa, Beograd.

Egan, T., (2008), A Non-Finite Complementation: A Usage-Based Study of Infinitive and -ing Clauses in English, Rodopi, Amsterdam and New York.

Filipović, R. (ed.), (1975), Contrastive Analysis of English and Serbo-Croatian, Vol., I. Institute of Linguistics, Faculty of Philosophy, University of Zagreb, Zagreb.

Filipović, R., (1975), „Kontrastivna lingvistika u svijetu i u nas”. Treći program Radio Beograda, 25, pp. 415-432.

Fries, C., (1945), Teaching and Learning English as a Foreign Language, Ann Arbor, University of Michigan Press, Michigan.

Greenbaum, S., (1996), The Oxford English Grammar, Oxford University Press, Oxford.

Halliday, M. A. K., A. McIntosh and P. Strevents., (1964), The Linguistic Sciences and Language Teaching, Longmans, London. 
Huddleston, R. and G. K. Pullum, (2002), The Cambridge Grammar of the English Language, Cambridge University Press, Cambridge.

James, C., (2013), Errors in Language Learning and Use: Exploring Error Analysis, Routledge, London and New York

Jespersen, O., (1933), Essentials of English Grammar, Routledge, London.

Jie, X., (2008), "Error Theories and Second Language Acquisition". US - China Foreign Language Vol. 6, Issue 1 pp. 35-42, http://connection.ebscohost.com/c/articles/32186787/error-theories-second-languageacquisition

Johansson, S. and K. Hofland, (1994), "Towards an English-Norwegian parallel corpus", U. Fries, G. Tottie and P. Schneider (eds.), Creating and using English language corpora, GA: Rodopi, Amsterdam and Atlanta, pp. 25-37.

Klajn, I., (2005), Gramatika srpskog jezika, Zavod za udžbenike i nastavna sredstva, Beograd.

Krzeszowski, T. P., (1985),'The so-called 'sign theory' as the first method in contrastive linguistics”, U. Pieper and G. Stickel (eds.), Studia linguistica diachronica et synchronica, Mouton De Gruyler, Berlin, pp. 485-501.

Kurteš, S., (2005),"Contrastive linguistics: a 21 st century perspective”, S. Marmaridou et al. (eds.). Reviewing linguistic thought: converging trends for the 21st century, (Trends in Linguistics: Studies and Monographs) Mouton de Gruyter, Berlin, pp. 255-278.

Kurteš, S., (2009),"New horizons for contrastive analysis: grammatical prototypes as tertium comparationis". Selected Papers from the 18th ISTAL, pp. 233-241, http://ejournals.lib.auth.gr/thal/article/view/5442

Lado, R., (1957), Linguistics across Cultures, Ann Arbor, University of Michigan Press, Michigan

Lee, R. W., (1974), "The Contribution of Contrastive Linguistics to the Preparation of Language-Teaching Materials", Monograph Series on Languages and Linguistics, No. 21, Georgetown University, School of Language and Linguistics, James E. Alatis (ed.), Georgetown University Press, Washington D. C., (2007), pp. $185-195$.

Mackey, W. F., (1965), Language Teaching Analysis, Longman, London.

Mathesius, V., (1964), "On linguistic characterology with illustrations from Modern English", J. Vachek (ed.). A Prague School Reader in Linguistics, Indiana University Press, Bloomington, pp. 59-67.

Mišić Ilić, B., (2008), Syntax for EFL Students, Filozofski fakultet Niš, Niš.

Mrazović, P., (2009), Gramatika srpskog jezika za strance, Izdavačka knjižarnica Zorana Stojanovića, Sremski Karlovci i Novi Sad.

Nemser, W., (1971), "Recent Center activities in contrastive linguistics", R. Filipović (ed.), B. Studies, 4, Zagreb Conference on English Contrastive Projects, 7-9 December 1970. Papers and Discussions, Institute of Linguistics, Zagreb, pp. 11-30.

Piper, P., I. Antonić, V. Ružić, S. Tanasić, Lj. Popović, B. Tošović, (2005), Sintaksa savremenoga srpskog jezika. Prosta rečenica, Milka Ivić (ed.), Institut za srpski jezik SANU, Beogradska knjiga, Matica srpska, Beograd.

Piper, P., I. Klajn, (2013), Normativna gramatika srpskog jezika, Matica srpska, Novi Sad.

Pollock, C., (1982), Communicate What You Mean, Prentice Hall, Eaglewood Hill, New Jersey.

Quirk, R. et al., (1985), A Comprehensive Grammar of the English Language, Longman, London.

Richards, J., (1971), "Error Analysis and Second Language Strategies". The text of an invited lecture given at Indiana University, Bloomington.

Schachter, J., (1974), "An Error in Error Analysis", Language Learning, Vol. 24, Issue 2, Amherst, Massachusetts, pp. 205-214.

Selinker, L., (2008), Second Language Acquisition, Routledge, New York and London.

Stanojčić, Ž., (2010), Gramatika srpskog književnog jezika, Kreativni centar, Beograd.

Stanojčić, Ž., i Lj. Popović, (1992), Gramatika srpskog jezika, Udžbenik za I, II, III i IV razred srednje škole, Zavod za udžbenike i nastavna sredstva, Zavod za izdavanje udžbenika, Beograd i Novi Sad.

Stevanović, M., (1991), Savremeni srpskohrvatski jezik (gramatički sistemi i književnojezička norma) II Sintaksa, peto izdanje, Naučna knjiga, Beograd.

Wang, P., (2008), "Exploring Errors in Target Language Learning and Use: Practice Meets Theory", English Language Teaching, Vol. I, No. 2. pp. 182-187. 


\section{ENGLESKE I SRPSKE NOMINALNE FINITNE I NEFINITNE KLAUZE U KONTRASTU}

Predmet ovog rada jeste da se ispita u kojoj meri srpski studenti engleskog jezika na tercijarnom nivou učenja koriste, odnosno izbegavaju da koriste nefinitne nominalne klauze u engleskom jeziku. Stoga se rad sastoji iz teorijskog dela, u kome se nominalne finitne i nefinitne klauze u engleskom $i$ srpskom jeziku opisuju i klasifikuju sa ciljem da se ove gramatičke strukture kontrastriraju na osnovu njihove sintaksičke funkcije subjekta i komplementa $i$ empirijskog, u kome se predstavljaju rezultati istraživanja sprovedenog na osnovu teorijske analize. Osnovne metode koje se koriste u radu su kontrastivna analiza, deskripcija i klasifikacija. Ovako dobijen kontrastivni model navodi na zaključak da su razlike očigledne u broju posebnih sintaksičkih funkcija koje ove klauze obavljaju u oba jezika kao $i$ u raznovrsnosti forme. Rezultati teorijske analize ispitani su kroz empirijsko istraživanje sprovedeno sa srpskim studentima engleskog jezika na tercijarnom nivou učenja. Studenti, podeljeni u dve grupe, eksperimentalnu i kontrolnu, imali su zadatak da prevedu zadate finitne nominalne klauze iz upitnika sa srpskog na engleski jezik. Dobijeni prevodi analizirani su na osnovu toga da li su student koristili finitne ili nefinitne klauze prilikom prevođenja. Rezultati empirijskog istraživanja potvrdili su teorijske postavke. Naime, studenti su uglavnom izbegavali da koriste nefinitne nominalne klauze u engleskom jeziku prilikom prevođenja zadatih rečenica iz upitnika

Ključne reči: srpski studenti engleskog jezika, kontrastivna analiza, finitne klauze, nefinitne klauze 